\title{
DUAL CAPACITY FOR NUTRIENT UPTAKE IN TETRAHYMENA IMPORTANCE OF THE ORAL UPTAKE SYSTEM FOR FE AND CU UPTAKE
}

\author{
by \\ LEIF RASMUSSEN \\ EDUARDO ORIAS*) \\ The Biological Institute of the Carlsberg Foundation \\ 16 Tagensvej, DK-2200 Copenhagen $N$ \\ *) on sabbatical leave of absence from Department of Biological Sciences, University of California, \\ Santa Barbara, Calif. 93106, U.S.A.
}

Key words: Tetrahymena pyriformis. ciliate - Food-vacuole-less mutant - Uptake of $\mathrm{Fe}$ and $\mathrm{Cu}$

We have reported that a mutant of Tetrahymena pyriformis with heat-sensitive development of the oral apparatus can be grown indefinitely without food vacuoles if the medium is supplemented with folinic acid and a mixture of trace metal salts. We report here that the trace metal mixture can be replaced completely and specifically by salts of iron and copper. $\mathrm{Fe}$ (II) and $\mathrm{Fe}(\mathrm{III})$ are interchangeable. Addition of citrate has proven useful to reduce precipitate formation and improve the reproducibility of growth of the mutant cell. Thus it appears to serve as an Fe buffer.

From the increased concentrations of $\mathrm{Fe}$ and $\mathrm{Cu}$ required to permit good growth of the mutant strain at $37^{\circ} \mathrm{C}$, we conclude that the oral uptake system plays a much more important role in the case of these two metals than the surface uptake system. The oral uptake system may facilitate Fe uptake in at least two ways: a) by a mechanical concentration of precipitates affected by the ciliary membranelles surrounding the oral cavity and, $b$ ) by lowering of the $\mathrm{pH}$ of the food vacuole and thereby releasing Fe from precipitates and from complexes which cannot be transported across the membrane as such. The second factor may also be important in $\mathrm{Cu}$ uptake.

A specific effect of $\mathrm{Mg}$ and $\mathrm{Fe}$ uptake or retention in the mutant strain growing without food vacuoles has been detected. The significance of this effect remains unclear.

Practical implications of the findings are discussed. 


\section{INTRODUCTION}

Relative roles of oral and surface uptake in the nutrition of Tetrahymena have posed important questions. The availability of a Tetrahymena mutant with a heat-sensitive capacity to form food vacuoles (12) permitted a new attack on this problem. The strain can be indefinitely propagated in growth media supplemented with vitamins and trace metals at high concentrations (15). This paper shows that the trace metals can be replaced with $\mathrm{Fe}$ and $\mathrm{Cu}$ salts; possible roles of the uptake system for the uptake of $\mathrm{Fe}$ and $\mathrm{Cu}$ are discussed.

\section{MATERIALS AND METHODS}

\subsection{Strains}

The wild type parental inbred strain D of Tetrahymena pyriformis, mating type III of syngen 1, and the mutant strain NPI have been used. The phenotype of strain NPI has been described previously (12). It forms no food vacuoles at $37^{\circ} \mathrm{C}$.

\subsection{Media}

The basal medium which supports optimal growth of the wild type strain consists of $2 \%$ proteose peptone broth, supplemented with 36 $\mu \mathrm{M}$ Fe salts, supplied either as $\mathrm{Fe}(\mathrm{II})$ or $\mathrm{Fe}(\mathrm{III})$. This medium was routinely supplemented with $2 \mathrm{mM}$ tri-sodium citrate, dihydrate, to avoid formation of precipitates, and is designated medium I or MI. In some early experiments this medium was supplemented with the vitamins of the chemically defined medium (14), either in the standard, low concentrations (vit-MI) or in the high concentrations of $1 \mathrm{mg} / 1$ (Vit-MI).

The medium which supports growth of the mutant cell, NPl, at the restrictive temperature, $37^{\circ} \mathrm{C}$, consists of $2 \%$ proteose peptone broth supplemented with $2 \mathrm{mM}$ tri-sodium citrate, dihydrate, $0.9 \mathrm{mM}$ ferrous ammonium sulphate, $50 \mu \mathrm{M}$ copper sulphate and calcium folinate (1 $\mathrm{mg} / \mathrm{l})$ and is designated medium II, or MII. In early experiments this medium was supplemented with the trace metal salts of the chemically defined medium (14), either in the standard, low concentrations (tm-MII) or in 25fold higher concentrations (TM-MII), see
Table I

Trace metal salts of the chemically defined medium in standard $(\mathrm{tm})$ and in 25-fold higher concentrations (TM).

\begin{tabular}{l|rc|rr}
\hline & \multicolumn{2}{|c|}{$\mathrm{tm}$} & \multicolumn{2}{|c}{$\mathrm{TM}$} \\
\cline { 2 - 5 } & $\mu \mathrm{g} / 100 \mathrm{ml} \mu \mathrm{M}$ & $\mu \mathrm{g} / 100 \mathrm{ml}$ & $\mu \mathrm{M}$ \\
$\mathrm{Fe}\left(\mathrm{NH}_{4}\right)_{2}\left(\mathrm{SO}_{4}\right)_{2} \cdot 6 \mathrm{H}_{2} \mathrm{O}$ & 1400 & 36 & 35000 & 900 \\
$\mathrm{ZnSO}_{4} \cdot 7 \mathrm{H}_{2} \mathrm{O}$ & 450 & 15 & 11000 & 375 \\
$\mathrm{MnSO}_{4} \cdot 4 \mathrm{H}_{2} \mathrm{O}$ & 160 & 7.1 & 4000 & 180 \\
$\mathrm{CuSO}_{4} \cdot 5 \mathrm{H}_{2} \mathrm{O}$ & 30 & 1.2 & 750 & 30 \\
$\mathrm{Co}\left(\mathrm{NO}_{3}\right)_{2} \cdot 6 \mathrm{H}_{2} \mathrm{O}$ & 50 & 1.7 & 1250 & 43 \\
$\left(\mathrm{NH}_{4}\right)_{6} \mathrm{Mo}_{7} \mathrm{O}_{24} \cdot 4 \mathrm{H}_{2} \mathrm{O}$ & 10 & 0.08 & 250 & 2 \\
\hline
\end{tabular}

Table 1. This medium could be supplemented with the standard concentration of the vitamin complement from the chemically defined medium (vit-TM-MII) or with all the vitamins (14) supplied at $1 \mathrm{mg} / 1$ (Vit-TM-MII).

\subsection{Experimental procedures}

Cultures were grown at $37^{\circ} \mathrm{C}$ in either $1 \mathrm{ml}$ of medium in a $15 \mathrm{~mm} \times 150 \mathrm{~mm}$ test tube, or in 10 $\mathrm{ml}$ in screw-capped conical flasks of $125 \mathrm{ml}$ capacity. The cultures were not agitated. Cultures were routinely tested for the presence of vacuole-forming revertants of strain NPI.

\section{RESULTS}

\subsection{Growth stimulation of $\mathrm{NPI}$ by $\mathrm{Fe}$ and $\mathrm{Cu}$ ions} Cells grown in complete medium were inoculated into culture flasks containing complete medium without the trace metal mixture, but individually supplemented with each of the trace metal salts at the same concentration as in the complete medium (TM). Only the $\mathrm{Fe}$ (II)supplemented culture grew to an extent comparable to the culture fully supplemented with all six metal salts (Fig. 1, Panel B).

In order to determine if $\mathrm{Fe}$ (II) was a sufficient supplement, cells from the Fe(II)-supplemented culture were used to inoculate separate cultures of the same medium, but supplemented with each of the remaining trace metal ions at the concentration shown in Table I, column TM. These results are shown in Fig. 1, Panel C. As seen, only the culture supplemented with both $\mathrm{Fe}(\mathrm{II})$ and $\mathrm{Cu}(\mathrm{II})$ grew 


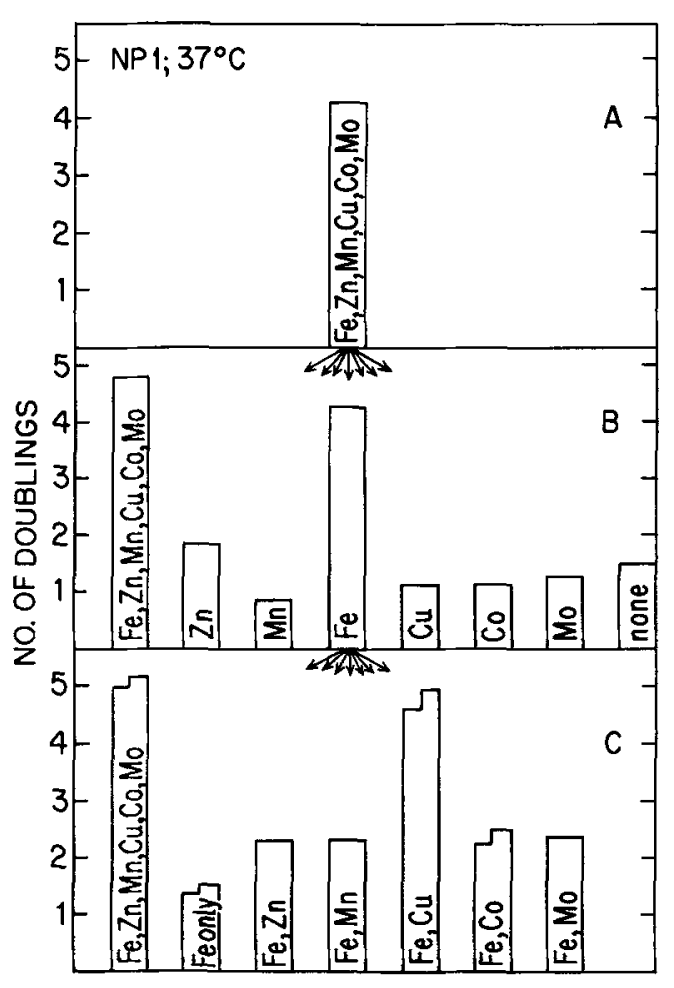

Figure 1. Identification of $\mathrm{Fe}$ and $\mathrm{Cu}$ ions as the important components of the trace metal mixture for growth of NPl at $37^{\circ} \mathrm{C}$. Panel $A$ : Growth of cells in Vit-TM-M(II) medium, containing all the trace metal salts in the concentration shown in the right column of Table I. Panel B: Growth of cells inoculated from the culture in Panel A into separate culture flasks. They contain all Vit-tm-M(I) medium and are individually supplemented with the metal salts indicated, supplied in 25 -fold the standard concentrations, TM. Panel $C$ : Growth of cells inoculated from the Fe supplemented culture in Panel B into flasks containing Vit-M(I) plus $1 \mathrm{mM} F e(I I)$, individually supplemented with the trace metal salts indicated in TM concentrations (Table I). The column to the left represents growth in a fully supplemented medium and the column next to it, growth in a culture supplemented with Fe only. Initial cell concentration in all cultures: 5000 cells per $\mathrm{ml}$; growth period: $16 \mathrm{hr}$.

as well as the fully-supplemented parallel culture. Serial subcultures of $\mathrm{NPl}$ in the $\mathrm{Fe}, \mathrm{Cu}$ supplemented medium continued to grow at the same rate as the fully supplemented cultures. Thus $\mathrm{Fe}$ and $\mathrm{Cu}$ salts at concentrations of $1 \mathrm{mM}$ and $50 \mu \mathrm{M}$, respectively, replaced the TM mixture in satisfying the trace metal deficiency experienced by NPI growing without food vacuole formation.

\subsection{The Fe requirement}

\subsubsection{Are $\mathrm{Fe}(I I)$ and $\mathrm{Fe}(I I I)$ equivalent?}

Dose response curves to these Fe-compounds are shown in Fig. 2. Fe(II) and Fe(III) satisfied the iron requirement equally well. The optimum response is obtained at 1-2 $\mathrm{mM}$. Since the two forms of iron are rather easily interconvertible, the relative proportion of the two forms in the medium is unknown.

\subsubsection{Does citrate induce the Fe requirement?}

To be sure that citrate was not enhancing the Fe requirement, the dose response experiment above was repeated, but citrate was omitted from the medium. The results obtained with $\mathrm{Fe}(\mathrm{III})$ are shown in Fig. 3. Comparison with Panel A of Fig. 2 shows that no significant difference was introduced by adding citrate. Thus citrate, even though it chelates $\mathrm{Fe}$, still allows enough $\mathrm{Fe}$ to be taken up.

The results obtained with $\mathrm{Fe}(\mathrm{II})$ in the absence of citrate are not shown. Although qualitatively similar results were obtained, the cultures without citrate showed much variation between duplicate flasks. We assume that the amount and nature of the Fe precipitates and their availability to the cells varied from culture to culture. These results also clearly show the utility of adding citrate to the medium to keep Fe uniformly available.

\subsubsection{Specificity of the Fe requirement}

Is Fe specifically the element which limits the NPl cells when they are unable to form food vacuoles at $37^{\circ} \mathrm{C}$ ? It is not sufficient to show that $\mathrm{Fe}$ restores a good growth rate. A different and active metal ion could be a contaminant in the commercial Fe preparation, or could be complexed to a component of the medium, but be displaced by $\mathrm{Fe}$, and thus made available to the NPl cells.

We therefore determined whether Fe could be replaced with other salts required by living systems. The results shown in Fig. 1, Panel B, already suggested that the active metal ion was not likely to be $\mathrm{Zn}, \mathrm{Mn}, \mathrm{Cu}, \mathrm{Co}$ and $\mathrm{Mo}$. In addition, $\mathrm{V}, \mathrm{B}, \mathrm{Cr}$ and $\mathrm{Ni}$ were tested together. The results gave no evidence that any of these metal ions can replace $\mathrm{Fe}$, even at con- 


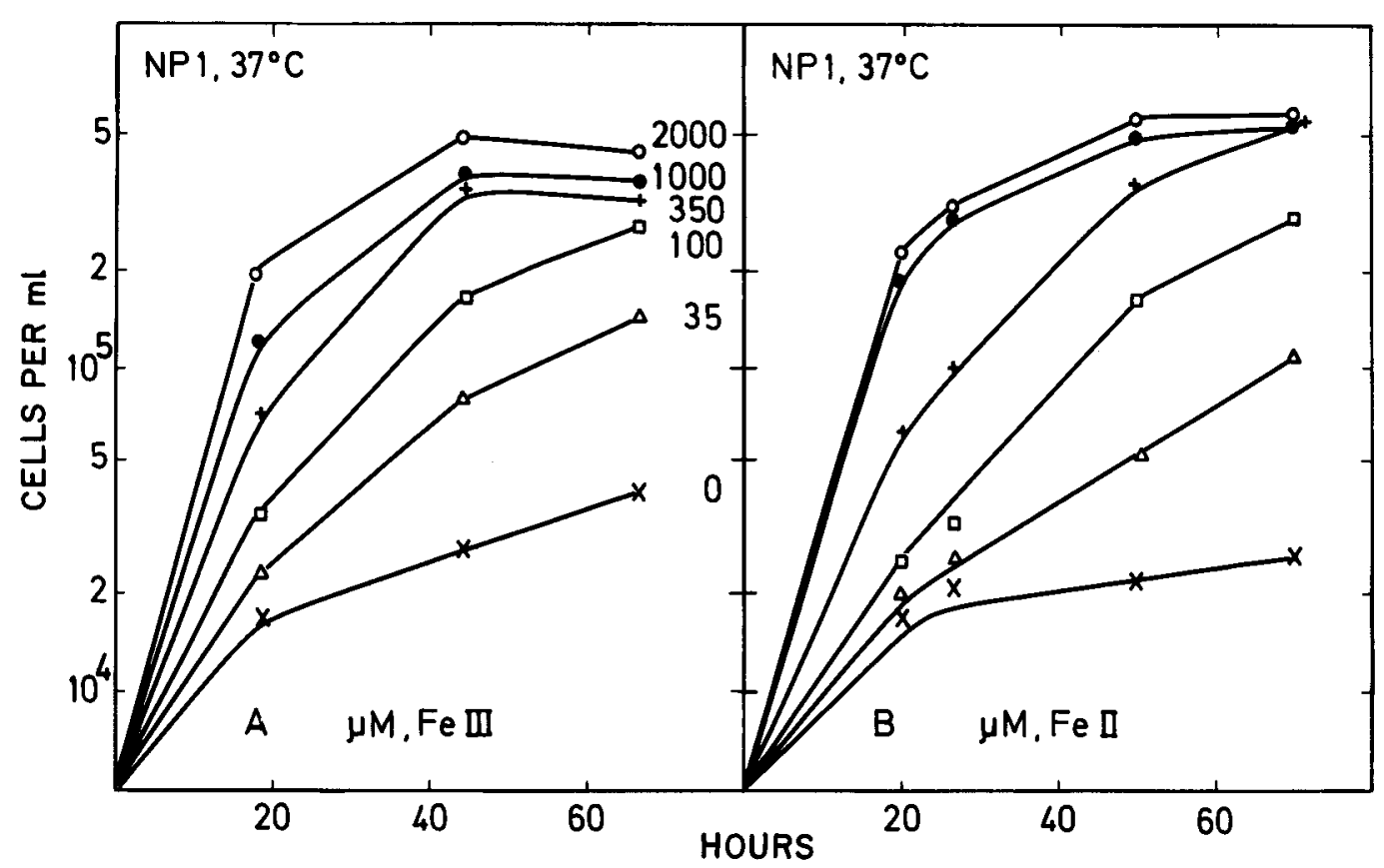

Figure 2. Response of strain NPl to ferric chloride (Panel A) and ferrous ammonium sulphate (Panel B) at $37^{\circ} \mathrm{C}$. The numbers associated with each of the curves represent the $\mathrm{Fe}$ salt concentration $(\mu \mathrm{M})$. Composition of the medium: MII (see Table I) minus $\mathrm{Fe}$ plus varying concentrations of Fe. Source of inoculum: NPl cells depleted for Fe.

centrations higher than those they might have as contaminants of the Fe preparations (Table II).

Metal ions which have higher affinities for organic ligands ( $\mathrm{Cu}(\mathrm{II}), \mathrm{Zn}(\mathrm{II}), \mathrm{Ni}(\mathrm{II}), \mathrm{Co}(\mathrm{II}))$ were then tried at high concentrations, up to 3 $\mathrm{mM}$, Table III. If $\mathrm{Fe}$ was not the principal active ion, then some of these ions might displace it from a complex not available to the cell, and thus be able to replace Fe. Even though the other ions tested allowed some residual multiplication of the cells, apparently none of them can replace $\mathrm{Fe}$.

From the inability to replace $\mathrm{Fe}$ with other trace metals, we conclude that it is very likely that the NPI cells are actually starved for Fe under conditions in which they cannot form food vacuoles.

\section{3 $\mathrm{Cu}$ requirement}

\subsubsection{Growth rates of $\mathrm{NPl}$ as function of $\mathrm{Cu}$} concentration

The optimum $\mathrm{Cu}$ concentration for the growth

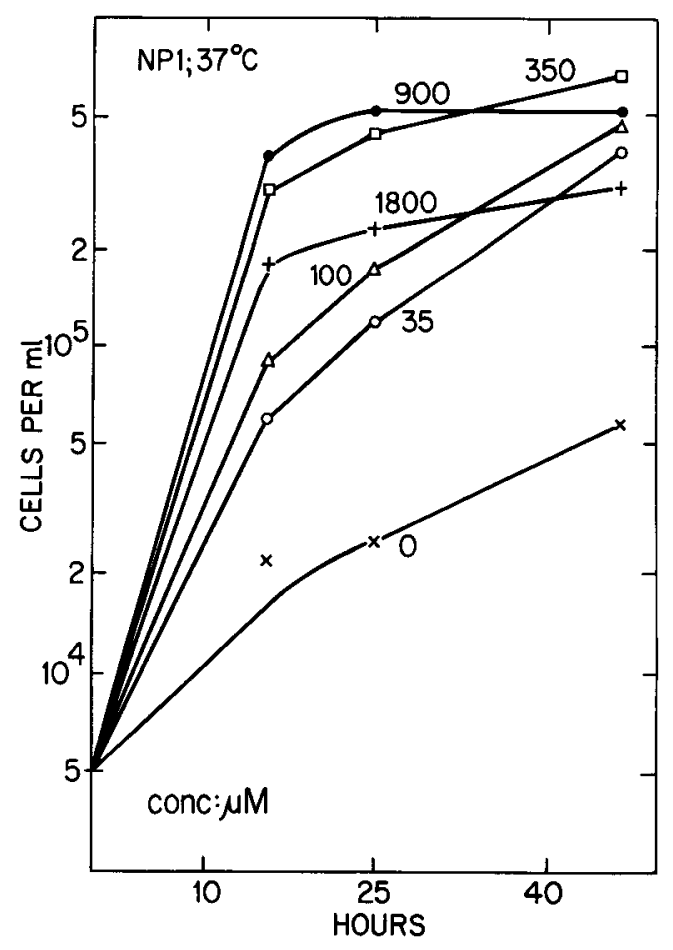

Figure 3. Response of strain NPI to ferric chloride in the absence of sodium citrate. Composition of the medium: MII minus citrate and Fe plus varying concentrations of Fe. Source of inoculum: NPI cells depleted for $\mathrm{Fe}$. 
Table II

Inability of $\mathrm{V}, \mathrm{B}, \mathrm{Ni}$, and $\mathrm{Cr}$ to replace $\mathrm{Fe}$ in stimulating growth of NPI cells at $37^{\circ} \mathrm{C}$.

\begin{tabular}{|c|c|c|c|}
\hline \multirow[b]{2}{*}{ Medium } & \multicolumn{3}{|c|}{$10^{3}$ cells per $\mathrm{ml}$ after } \\
\hline & $0 \mathrm{~h}$ & $20 \mathrm{~h}$ & $42 \mathrm{~h}$ \\
\hline $\mathrm{M}$ II minus $\mathrm{Fe}$ & 2 & 8 & 11 \\
\hline$+\mathrm{V}, \mathbf{B}, \mathrm{Ni}, \mathrm{Cr}-\mathrm{mix}$ & 2 & 8 & 11 \\
\hline$+\mathrm{Fe}(\mathrm{II})$ & 2 & 91 & 333 \\
\hline $\mathrm{Ni}, \mathrm{Cr}-\mathrm{mix}$ & 2 & 102 & 257 \\
\hline
\end{tabular}

M II medium: $2 \%$ proteose peptone broth supplemented with $2 \mathrm{mM}$ tri-sodium citrate, $1 \mathrm{mg}$ calcium folinate $\Lambda, 1 \mathrm{mM}$ ferrous ammonium sulphate and $50 \mu \mathrm{M}$ copper sulphate.

Source of inoculum: early stationary NPI cells grown in $\mathrm{M}$ II medium. Fe (II): ferrous ammonium sulphate. The V, B, Ni, Cr-mix provided (mg/l): $\mathrm{NH}_{4} \mathrm{VO}_{3}: 4.6$; $\mathrm{H}_{3} \mathrm{BO}_{3}: 5.7 ; \mathrm{NiSO}_{4} .6 \mathrm{H}_{2} \mathrm{O}: 4.5 ; \mathrm{CrK}\left(\mathrm{SO}_{4}\right)_{2} .12 \mathrm{H}_{2} \mathrm{O}: 9.6$. These concentrations are 10 times higher than recommended by Hutner (7).

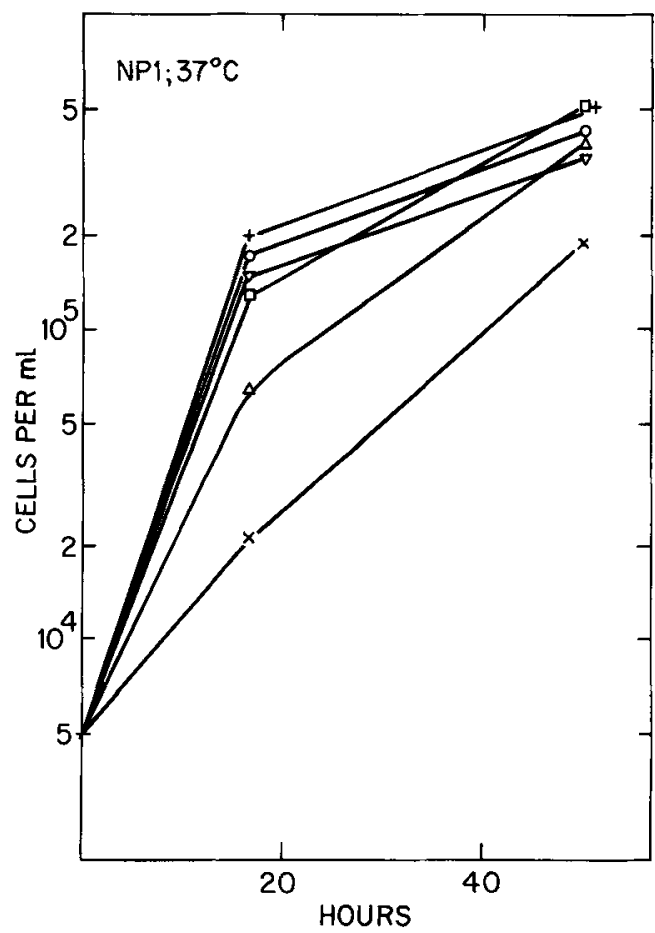

Figure 4. Response of strain NPI to copper sulphate at $37^{\circ} \mathrm{C}$. Composition of the medium: Vit-TM-MII minus $\mathrm{Cu}$ plus varying concentrations of $\mathrm{Cu}$. The curves from below represent growth responses to 0 , $1.25,4,12.5,40,125 \mu \mathrm{M}, \mathrm{Cu}$ respectively. Source of inoculum: NPI cells grown for two transfers without addition of $\mathrm{Cu}$.
Table III

Inability of $\mathrm{Cu}, \mathrm{Zn}, \mathrm{Ni}$ and $\mathrm{Co}$-ions at high concentrations to replace $\mathrm{Fe}$ in stimulating growth of NPI cells at $37^{\circ} \mathrm{C}$.

\begin{tabular}{|c|c|c|c|c|}
\hline \multirow{2}{*}{\multicolumn{2}{|c|}{ Medium }} & \multicolumn{3}{|c|}{$10^{3}$ cells per ml after } \\
\hline & & $0 \mathrm{~h}$ & $17 \mathrm{~h}$ & $41 \mathrm{~h}$ \\
\hline \multicolumn{2}{|c|}{$\begin{array}{l}\text { M II minus } \mathrm{Fe} \\
\text { M II minus } \mathrm{Fe}+\mathrm{Fe}(\mathrm{III})\end{array}$} & 1 & 4 & 7 \\
\hline 0.63 & $\mathrm{mM}$ & 1 & 26 & 260 \\
\hline 1.3 & - & 1 & 30 & 300 \\
\hline 2.5 & - & 1 & 70 & 440 \\
\hline 3.0 & - & 1 & $x$ & $x$ \\
\hline \multicolumn{2}{|c|}{$\mathrm{M} \mathrm{II} \mathrm{minus} \mathrm{Fe}+\mathrm{Cu}$} & & & \\
\hline 0.5 & $\mathrm{mM}$ & 1 & 3 & 9 \\
\hline 1.0 & - & 1 & 3 & 6 \\
\hline 2.0 & - & 1 & 3 & 3 \\
\hline 3.0 & - & 1 & 2 & 1 \\
\hline \multicolumn{2}{|c|}{$\mathrm{M}$ Il minus $\mathrm{Fe}+\mathrm{Zn}$} & & & \\
\hline 0.5 & $\mathrm{mM}$ & 1 & 4 & 10 \\
\hline 1.5 & - & l & 4 & 7 \\
\hline 2.0 & - & 1 & 4 & 7 \\
\hline 3.0 & - & 1 & 4 & 8 \\
\hline \multicolumn{2}{|c|}{$\mathrm{M}$ II minus $\mathrm{Fe}+\mathrm{Ni}$} & & & \\
\hline 0.5 & $\mathrm{mM}$ & 1 & 4 & 17 \\
\hline 1.0 & - & 1 & 4 & 22 \\
\hline 2.0 & - & 1 & 3 & 7 \\
\hline 3.0 & - & 1 & 7 & $\mathrm{x}$ \\
\hline \multicolumn{2}{|c|}{$\mathrm{M} \mathrm{II} \mathrm{minus} \mathrm{Fe}+\mathrm{Co}$} & & & \\
\hline 0.5 & $\mathrm{mM}$ & 1 & 4 & 8 \\
\hline 1.0 & - & 1 & 5 & 6 \\
\hline 2.0 & - & 1 & 3 & 1 \\
\hline 3.0 & - & 1 & $x$ & $\mathbf{x}$ \\
\hline \multicolumn{2}{|l|}{ M II } & 1 & 80 & 260 \\
\hline
\end{tabular}

M II: see legend for Table II. Fe (III): ferric chloride. Salts provided as sulphates, except for cobalt nitrate. Source of inoculum: 100-fold dilution of an early stationary phase culture grown in M II medium. $x$ means that the cells died.

of strain NPl at $37^{\circ} \mathrm{C}$ was determined in Fig. 4. The optimum growth rate is obtained at 12.5 $\mu \mathrm{M}$. At higher concentrations (up to $125 \mu \mathrm{M}$ ) there appears to be a slight inhibition. Even though the growth rate is low, the maximum yield of cells is eventually obtained even when $\mathrm{Cu}$ is not added to the medium.

\subsubsection{Specificity of the Cu requirement}

The results in Fig. 1, Panel C, already indicated 
$\underline{\text { Table IV }}$

Inability of various metal ions to replace $\mathrm{Cu}$ in stimulating growth of $\mathrm{NPl}$ cells at $37^{\circ} \mathrm{C}$.

\begin{tabular}{|c|c|c|c|}
\hline Medium & \multicolumn{3}{|c|}{$\begin{array}{l}10^{3} \text { cells per ml after } \\
0 \mathrm{~h}|19 \mathrm{~h}| 43 \mathrm{~h}\end{array}$} \\
\hline $\begin{array}{l}\text { Experiment } \mathbf{l} \\
\begin{array}{l}\mathrm{M} \text { II minus } \mathrm{Cu} \\
\quad+\mathrm{V}, \mathrm{B}, \mathrm{Ni}, \mathrm{Cr}\end{array} \\
\begin{array}{l}\mathrm{M} \text { II } \quad+\mathrm{V}, \mathrm{B}, \mathrm{Ni}, \mathrm{Cr}\end{array}\end{array}$ & $\begin{array}{l}1 \\
1 \\
1 \\
1\end{array}$ & $\begin{array}{l}11 \\
11 \\
72 \\
84\end{array}$ & $\begin{array}{r}87 \\
86 \\
340 \\
340\end{array}$ \\
\hline Experiment 2 & $0 \mathrm{~h}$ & $15 \mathrm{~h}$ & $42 \mathrm{~h}$ \\
\hline $\begin{aligned} \text { M II minus } \mathrm{Cu} \\
+5 \mathrm{mM} \mathrm{Ca} \\
+5 \mathrm{mM} \mathrm{Mg} \\
+50 \mu \mathrm{M} \mathrm{Cu}\end{aligned}$ & $\begin{array}{l}1 \\
1 \\
1 \\
1\end{array}$ & $\begin{array}{r}29 \\
31 \\
35 \\
122\end{array}$ & $\begin{array}{l}340 \\
340 \\
340 \\
420\end{array}$ \\
\hline
\end{tabular}

M II: see legend of Table II. Source of inoculum: early stationary NPl cells, grown in same medium for one transfer (about 7 fissions) in expt.1, and for two transfers (about 15 fissions) in expt. 2. Metals were supplies as follows: $\mathrm{Ca}$ as calcium chloride, dihydrate; $\mathrm{Mg}$ as magnesium sulphate, heptahydrate. $\mathrm{V}, \mathrm{B}, \mathrm{Ni}, \mathrm{Cr}$ : as in Table II. The metal salts solutions were sterilized by filtration and added aseptically to the culture medium.

that $\mathrm{Zn}, \mathrm{Mn}, \mathrm{Co}$ and Mo did not replace $\mathrm{Cu}$, even at concentrations higher than those they might have as contaminants of commercial $\mathrm{Cu}$ salts. Four other metals (V, B, Cr and Ni) were also tested in this respect (Table IV). The results gave no evidence that any of these metals could replace $\mathrm{Cu}$. Thus the NPI cells growing without food vacuoles appear to be starved for $\mathrm{Cu}$ as well as for $\mathrm{Fe}$.

\subsubsection{Is the elevated $C$ u requirement induced by the high Fe concentration?}

Since high concentrations of $\mathrm{Fe}$ are added to the medium, the $\mathrm{Cu}$ requirement might be only a secondary consequence of this addition. This could occur if, for example, there was competition for a common uptake system. Such interactions, involving other metal combinations, have been documented (1). We therefore determined whether the wild type parental strain, DIII, showed a higher $\mathrm{Cu}$ requirement when grown at high $\mathrm{Fe}$ concentrations. This was not the case (Table V). We interpret this to mean that a high concentration of $\mathrm{Fe}$ does not
Table V

Lack of $\mathrm{Cu}$ requirement induced by high concentration of Fe in the wild type strain at $37^{\circ} \mathrm{C}$.

\begin{tabular}{l|c|c|c}
\hline \multirow{2}{*}{ Cells kept in } & \multicolumn{3}{|c}{$10^{3}$ cells per ml after $18 \mathrm{~h}$} \\
\cline { 2 - 4 } & $\begin{array}{c}\text { 1st } \\
\text { transfer }\end{array}$ & $\begin{array}{c}\text { 2nd } \\
\text { transfer }\end{array}$ & $\begin{array}{c}\text { 3rd } \\
\text { transfer }\end{array}$ \\
\hline M I minus Fe+1 mM & & & \\
Fe (II) & 383 & 340 & 370 \\
M I minus Fe+1 mM & 352 & 350 & 360 \\
Fe (II) +50 $\mu \mathrm{M} \mathrm{Cu}$ & 352 \\
\hline
\end{tabular}

Cells were subcultured in the appropiate medium every day, at an initial concentration of 1000 cells per $\mathrm{ml}$.

M I: see Methods section. Fe (II): ferrous ammonium sulphate.

interfere with $\mathrm{Cu}$ uptake by the food vacuole route. We cannot rule out, however, an interference of $\mathrm{Fe}$ with the uptake of $\mathrm{Cu}$ through the secondary route that becomes the main source of $\mathrm{Cu}$ uptake for NPl in the absence of food vacuoles.

\subsection{Effect of $\mathrm{Mg}$ at limiting Fe concentrations}

As a part of the test of the specificity of $\mathrm{Fe}$ in stimulating $\mathrm{NPI}$ growth at $37^{\circ} \mathrm{C}, \mathrm{Ca}$ and $\mathrm{Mg}$ were included (Fig. 5). Surprisingly, $\mathrm{Mg}$ - but not $\mathrm{Ca}$ - stimulated growth of NPl significantly under Fe-deficient conditions. The effective concentrations were high, approximately 5 $\mathrm{mM}$.

We tested for the possibility that a similar effect of $\mathrm{Mg}$ would be observed for the wild type strain under conditions of Fe deficiency. The results showed no evidence of a similar effect of either $\mathrm{Ca}$ or $\mathrm{Mg}$ on strain DIII, Table VI. Thus the effect of $\mathrm{Mg}$ in Fe starved cells appears to be specific for NPI.

The results in Table IV, exp. 2, showed no effect of $\mathrm{Mg}$ on $\mathrm{Cu}$ starved cells; thus it appears that the effect of $\mathrm{Mg}$ is relatively specific for $\mathrm{Fe}$.

\section{DISCUSSION}

\section{1 $\mathrm{Cu}$ and $\mathrm{Fe}$ requirement of strain $\mathrm{NPI}$ at $37^{\circ} \mathrm{C}$}

Studies on growth requirements of a food vacuole-less mutant have forcefully called attention to the dual uptake capacity of $T$. 


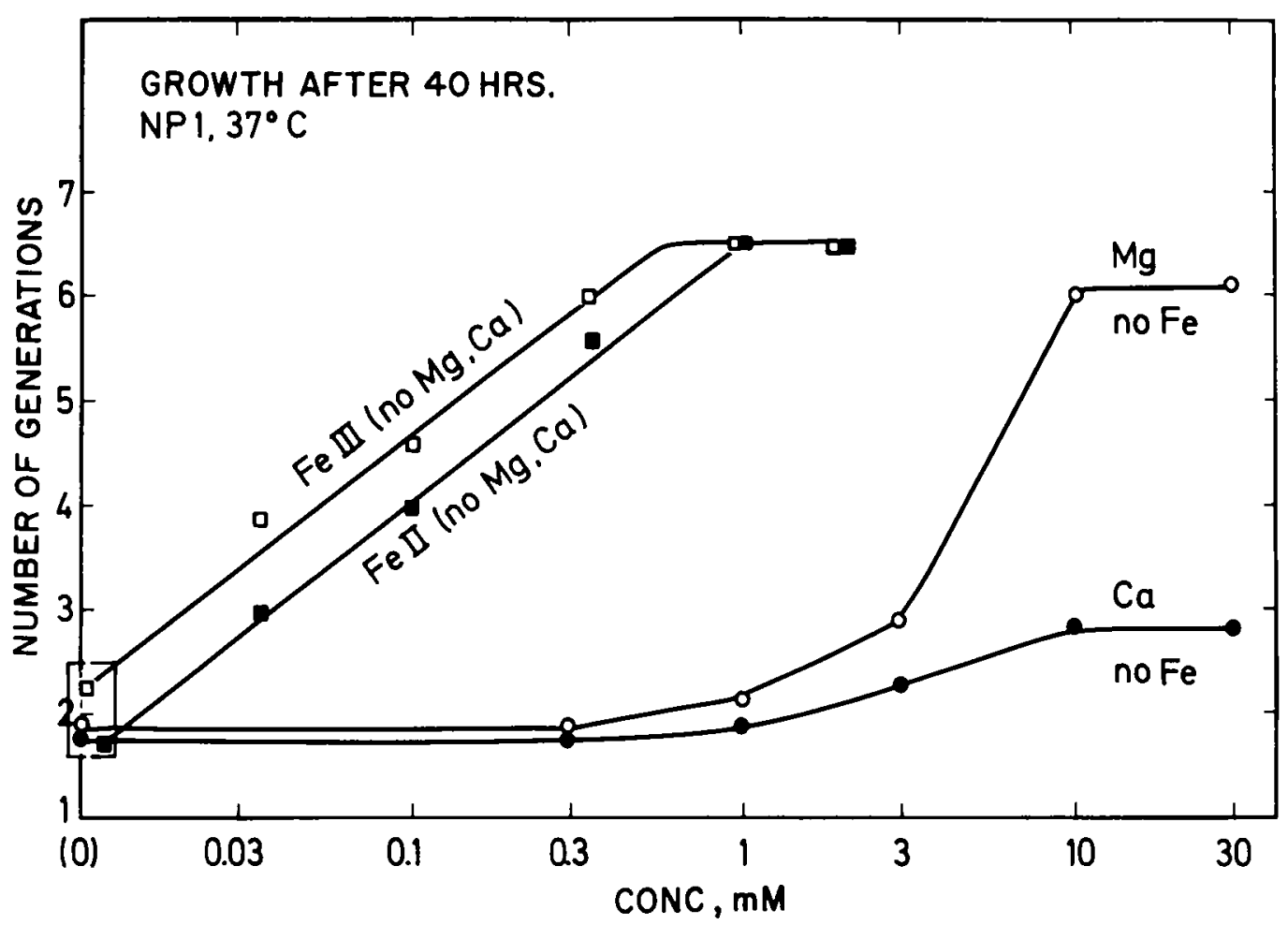

Figure 5. Dose response curves of strain NPl at $37^{\circ} \mathrm{C}$ to the addition of $\mathrm{Ca}$ and $\mathrm{Mg}$ ions under conditions of Fe-starvation. Nutrient substrate: MII minus Fe. Source of inoculum: NPl cells grown at $37^{\circ} \mathrm{C}$ in MII. Initial concentration 2000 cells per $\mathrm{ml}(\mathrm{Ca}$ and $\mathrm{Mg}$ curves) and 5000 cells per $\mathrm{ml}$ (Fe curves). The dose response for addition of ferrous ammonium sulphate or ferric chloride is included for purposes of comparison. It has been obtained from the data plotted in Fig. 2. The composition of the medium for these Feaddition experiments differs slightly, in that all the vitamins and all the trace metals (except Fe) were added. These differences should not affect the results.

\section{Table VI}

Effect of high concentrations of $\mathrm{Ca}$ and $\mathrm{Mg}$ on $\mathrm{Fe}$ starved wild type cells.

\begin{tabular}{l|c|r|r}
\hline \multirow{2}{*}{ Medium } & \multicolumn{4}{|c}{$10^{3}$ Cells per ml after } \\
\hline M I minus Fe & $0 \mathrm{~h}$ & \multicolumn{1}{|c|}{$15 \mathrm{~h}$} & $42 \mathrm{~h}$ \\
$+5 \mathrm{mM} \mathrm{Ca}$ & 1 & 8 & 135 \\
$+5 \mathrm{mM} \mathrm{Mg}$ & 1 & 8 & 120 \\
$+0.36 \mathrm{mM} \mathrm{Fe}$ (III) & 1 & 9 & 150 \\
\hline
\end{tabular}

M I: see Methods section. Source of inoculum: DIII cells, propagated through two serial transfers (about 15 fissions) in the same basal medium.

$\mathrm{Mg}$ supplied as magnesium sulphate; $\mathrm{Ca}$ as calcium chloride; $\mathrm{Fe}$ (III): ferric chloride. Stock solutions were sterilized by filtration and added aseptically.

pyriformis: uptake mediated by the food vacuole (and accessory cell specializations), the oral uptake system (OUS) and uptake mediated by the cell membrane, the surface uptake system (SUS). We have argued that the mutant NPI has a genetically determined block of at least the food vacuole component of the OUS, and therefore we attribute nutritional differences between NPI and the wild type strains to the functioning of the OUS (12). We also assume (with some justification) that a blocked OUS is the only pertinent functional difference between $\mathrm{NPI}$ and the wild type strain at $37^{\circ} \mathrm{C}$ (unpubl. obs.). Given these assumptions, we interpret our results to mean that in the wild-type Tetrahymena the OUS system plays an important role in the uptake of $\mathrm{Fe}$ and $\mathrm{Cu}$ at the concentrations normally present in the standard growth media. Nevertheless the surface-uptake system can apparently mediate the uptake of adequate amounts of those compounds if provided in high enough concentrations.

4.2 Role of the OUS in the transport of $\mathrm{Fe}$ and $\mathrm{Cu}$ These conclusions raise the question: In what 
way can the OUS be so important for the uptake of these two metal ions? An important role for the hydrolytic enzymes of the food vacuole can be ruled out. However, as described below, the two compounds have properties that lead us to suggest that $\mathrm{pH}$ differences may be a major part of the explanation.

$\mathrm{Fe}$ (III) is probably never available at biologically meaningful concentrations as the simple hydrated complex $\mathrm{Fe}\left(\mathrm{H}_{2} \mathrm{O}\right)_{6}{ }^{{ }^{+}}$. On the one hand, in the absence of other complexing agents, it will polymerize to give oxo- and hydroxo-derivatives whose solubility product is about $10^{-36}(11)$. One the other hand, Fe(III) can also form strong complexes to organic ligands - particularly to the elements $\mathrm{O}, \mathrm{N}$ and $S(11)$ - which also have low dissociation constants (17). Complexes with only a few highly specialized ligands have been shown to be capable of being transported into cells $(3,16)$. Thus it has been pointed out that $\mathrm{Fe}$ presents a challenging uptake problem to single-cell, water-dwelling organisms at nearly neutral $\mathrm{pH}$ $(7,9,11,16)$. This challenge has been met by some bacteria by secretion of ferric ironophores which can wrest the iron away from precipitates and other complexes and then be transported into the cell, see reviews by Hutner (7), Neilands (11) and Byers (3).

Tetrahymena could well make use of another biological invention, namely the collection of nutrients into an internal, membrane-bound food vacuole, whose $\mathrm{pH}$ can be manipulated. The $\mathrm{pH}$ of Tetrahymena food vacuoles does not appear to have been studied. However, extensive studies in the related ciliate Paramecium suggest that the $\mathrm{pH}$ undergoes a programmed change during the "life cycle " of a food vacuole, and that it reaches values as low as $1-3(8,10$, 18). Since $\mathrm{H}^{+}$ions compete with the metal ion for the electron-donor groups of the ligand, a lowering of the $\mathrm{pH}$ increases the concentration of "free $\mathrm{Fe}(\mathrm{III})$, and could thus make it available to Fe-chelating groups associated with transport sites on the food vacuole membrane.

In unsupplemented $2 \%$ proteose peptone broth, all Fe may be complexed to soluble components, since filtration of the medium through Millipore membrane filters with $0.2 \mu \mathrm{m}$ reten- tion capacity does not change the concentration of the total $\mathrm{Fe}$ (about $0.2 \mu \mathrm{g} / \mathrm{ml}$ as measured by atomic absorption (Dr. S. (Christensen, pers. comm.)). Compounds known to complex $\mathrm{Fe}$ are present in the medium: amino acids (negative ions), peptides, nucleosides, vitamins etc., in addition to citrate. Another feature of the Tetrahymena OUS may come into play at higher concentrations of $\mathrm{Fe}$, where oxo- and hydroxo-precipitates may occur. This is the ability of the ciliary membranelles to concentrate particulate matter in the size range up to $5 \mu \mathrm{m}$. It has been estimated that the concentration factor for India ink particles (approximately $0.2-0.5 \mu \mathrm{m}$ in diameter) in the food vacuoles is around 500 (13). Thus the oral uptake system, through its remarkable capacity for mechanical concentration and for $\mathrm{pH}$ lowering, is well adapted to handle the geochemical and biological challenge posed by Fe. The hydrated form of $\mathrm{Cu}$ (II) does not present solubility problems nearly as serious as those of $\mathrm{Fe}(\mathrm{III})$. Cu does, however, form strong complexes with organic ligands. Indeed, among the remaining nutritionally most important transition elements ( $\mathrm{Zn}, \mathrm{Mn}, \mathrm{Cu}, \mathrm{Co}, \mathrm{Mo}, \mathrm{V}) \mathrm{Cu}(\mathrm{II})$ generally forms the strongest complexes (reviewed by ANGELICI (2)). Thus the OUS system may also significantly facilitate the uptake of $\mathrm{Cu}$, at least by lowering the $\mathrm{pH}$ and liberating the $\mathrm{Cu}$ from complexes which render it unavailable. Nothing is known about the ionophores involved in $\mathrm{Cu}$ transport across the cell membrane in Tetrahymena. Strain NPl may be a useful experimental system for the study of that mechanism.

\subsection{Fe and $\mathrm{Cu}$ uptake through the surface uptake system}

Fe uptake at $37^{\circ} \mathrm{C}$ by the SUS of strain NPI can be considered extremely poor at best. This suggests the absence of specialized chelators for Fe transport analogous to the catechols and hydroxamates produced by other unicellular organisms $(3,16)$. The dose response curves of NPI to Fe(III) are not significantly different in the presence or absence of citrate, and this suggests that the $\mathrm{Fe}(\mathrm{III})$-citrate complex is unavailable to the SUS, and that a citrate-de- 
pendent uptake system analogous to that in Salmonella does not play a nutritionally significant part in the SUS (18). The possibility remains that any of the above systems exists but is heat-sensitive in both strains, $i$. e., inactive at $37^{\circ} \mathrm{C}$. Heat-sensitive $\mathrm{Fe}$ uptake systems are known in certain wild type bacterial strains (5). The only role we ascribe to citrate in the growth of NPI at $37^{\circ} \mathrm{C}$ - and our only reason for adding it to the medium - is to serve as an Fe buffer, $i$. $e$, to chelate and thus solubilize the $\mathrm{Fe}$ precipitates which are otherwise formed. These precipitates introduce a source of variability from culture to culture, as they can interfere both with optical or electronic methods of cell counting, and with the fractionation and purification of cellular components. Whether $\mathrm{Fe}$ (III)-citrate complexes can be transported as such through the food-vacuole membrane is unknown.

\section{4 $\mathrm{Fe}$ and $\mathrm{Cu}$ requirements of the wild type strain} We have confirmed for strain GL and inbred strain D of syngen 1 CONNER and CLINE's observation for strain $W$ that $2 \%$ proteose peptone broth, even though it allows transplantable growth indefinitely, is nutritionally deficient for Tetrahymena (4). Fe corrects that deficiency. The addition of $36 \mu \mathrm{M}$ $\mathrm{Fe}(\mathrm{II})$ or (III) yields a maximum growth rate for GL and strain DIII.

\subsection{Mg stimulation of Fe-starved NPI cells}

$\mathrm{Mg}$ can stimulate the growth of Fe-starved NPI, but not wild type cells. This effect of $\mathrm{Mg}$ may be related to the uptake (or possibly the retention) of $\mathrm{Fe}$ by the cell surface system and is somewhat specific for $\mathrm{Fe}$. The finding that $\mathrm{Mg}$ is much more active than $\mathrm{Ca}$ tends to rule out the possibility that the $\mathrm{Mg}$ is simply displacing $\mathrm{Fe}$ (or some other metal) from a complex that sequesters that metal, since $\mathrm{Ca}$ in general has greater affinity than $\mathrm{Mg}$ for the organic ligands present in the growth medium (17). $\mathrm{Mg}$ may stimulate a membrane-located component of the Fe-transport system.

\section{ACKNOWLEDGEMENTS}

We thank Professor ERIK ZEUTHEN, head of the Biological Institute of the Carlsberg Founda- tion for valuable discussions at all stages of the present study. We also thank Drs. G. G. HoLz, Jr., S. H. Hutner and R. E. Pearlman for critical reading of the manuscript. Finally, we are indebted to Dr. S. CHRISTENSEN, Department of Physiology, University of Aarhus, for iron determinations of our nutrient media and Mrs. J. OrIAS and Mrs. B. DOHN for excellent technical assistance. We thank mag. scient. K. MAX MøLLER for helpful advice on problems of chelation. One of us, E. O., acknowledges gratefully support by NIH grant GM 21067 and by the Carlsberg Foundation, Copenhagen, Denmark.

\section{REFERENCES}

1. Albert, A. : Selective Toxicity. London: Methuen and Co. Ltd.: New York: John Wiley and Sons, Inc. (1960)

2. ANGELICI, R. J.: Stability of coordination compounds. In G. L. Eichorn (ed.) Inorganic Biochemistry, 63-101, Elsevier Scientific Publishing Company, Amsterdam-London-New York (1973)

3. BYERS, B. R.: Iron transport in gram-positive and acid-fast Bacilli. In J. B. Neilands (ed.) Microbial Iron Metabolism, 83-105. Academic Press, New York (1974)

4. Conner, R, L. \& S. G. Cline : Iron deficiency and the metabolism of Tetrahymena pyriformis. $J$. Protozool. 11:486-491 (1964)

5. Garibaldi, J. A.: Influence of temperature on the biosynthesis of iron transport compounds by Salmonella typhimurium. J. Bact. 110: 262-265 (1972)

7. Hutner, S. H.: Inorganic nutrition. Ann. Rev. Microbiol. 26: 313-346 (1972)

8. Kitchings, J. A.: Food vacuoles. Protoplasmatologia 3: Ch. D3b, 1-54 (1956)

9. Levanpowsky, M. \& S. H. Hutner: Utilization of $\mathrm{Fe}^{3}$ by the inshore colorless marine dinoflagellate Crypthecodinium cohnii. Ann. N. Y. Acad. Sci. 245: 16-25 (1975)

10. MAST, S. O.: The food vacuole in Paramecium. Biol. Bull. 92: $31-72$ (1947)

11. NeILANDS, J. B.: Iron and its role in microbial physiology. In J. B. Neilands (ed.) Microbial Iron Metabolism. A Comprehensive Treatise, 3-34. Academic Press, New York-London (1974)

12. Orias, E. \& N. A. Pollock: Heat-sensitive development of the phagocytotic organelle in a Tetrahymena mutant. Expt1. Cell. Res. 90: 345-357 (1975) 
13. Rasmussen L., H. E. Buhse, JR., \& K. GROH: Efficiency of filter feeding in two species of Tetrahymena. J. Protozool. 22: 110-111 (1975)

14. Rasmussen, L. \& L. Modeweg-Hansen: Cell multiplication in Tetrahymena cultures after addition of particulate material. J. Cell Sci. 12: 275 286 (1973)

15. RASMUSSEN, L. \& E. ORIAS: Tetrahymena: Growth without phagocytosis. Science 190: 464-465 (1975)
16. RosenberG, H. \& I. G. YOUNG: Iron transport in the enteric bacteria. In J. B. Neilands (ed.) Microbial Iron Metabolism, 67-82. Academic Press, New York-London (1974)

17. SilléN, L. G. \& A. E. Martell: Stability constants of metal-ion complexes. Special Publication No. 17 of the Chemical Society, Burlington House, London, W. 1. (1964)

18. Wichterman, R.: The Biology of Paramecium. The Blakiston Co., Inc., New-York-Toronto. (1953) 